\title{
Article \\ The Challenge of Teacher Training in the 2030 Agenda Framework Using Geotechnologies
}

\author{
Miguel-Ángel Puertas-Aguilar ${ }^{1}$, Javier Álvarez-Otero ${ }^{2}$ (i) and María-Luisa de Lázaro-Torres ${ }^{3, *(1)}$ \\ 1 International Doctoral School of the UNED (EIDUNED), 28015 Madrid, Spain; mpuertas48@alumno.uned.es \\ 2 Didactics of Experimental, Social and Mathematical Sciences Department, Complutense University of Madrid, \\ 28040 Madrid, Spain; javier.alvarez.otero@ucm.es \\ 3 Department of Geography, UNED, 28040 Madrid, Spain \\ * Correspondence: mllazaro@geo.uned.es
}

check for updates

Citation: Puertas-Aguilar, M.-Á.; Álvarez-Otero, J.; de Lázaro-Torres, M.-L. The Challenge of Teacher Training in the 2030 Agenda Framework Using Geotechnologies. Educ. Sci. 2021, 11, 381. https:// doi.org/10.3390/educsci11080381

Academic Editor: Eila Jeronen

Received: 8 June 2021

Accepted: 21 July 2021

Published: 26 July 2021

Publisher's Note: MDPI stays neutral with regard to jurisdictional claims in published maps and institutional affiliations.

Copyright: (c) 2021 by the authors. Licensee MDPI, Basel, Switzerland. This article is an open access article distributed under the terms and conditions of the Creative Commons Attribution (CC BY) license (https:// creativecommons.org/licenses/by/ $4.0 /)$.

\begin{abstract}
Social evolution, globalization, and advances in technology are making it increasingly necessary to offer complete and comprehensive teacher training. This training should produce citizens who are concerned about the planet and its future. These values are embedded in the Sustainable Development Goals (SDGs), the breadth of which allows them to be integrated into the secondary school curriculum for most subjects. To construct a complete teacher training model, the following have been considered: previous studies based on qualitative and quantitative methodologies (the Delphi method and questionnaires for 'expert' teachers), the teaching experience of the authors, the action research methodology, and validation by other teachers who use technologies and are concerned about sustainability issues. The result is a teacher training model that is in line with UNESCO's sustainability competencies and based not only on technology, the scientific content of the subject to be taught, and didactics (pedagogy), but also on education in sustainability and the SDGs that need to be integrated. This approach is expected to produce changes in citizens' attitudes that contribute to the achievement of the SDGs and lead to the teachers feeling positive about their teaching experiences. However, a systematic application of this approach in classrooms and an assessment of its learning results are still pending.
\end{abstract}

Keywords: education; learning; technology; teacher training; sustainable development goals (SDGs); Web GIS; socioemotional intelligence; education for sustainability (EfS)

\section{Introduction}

The recent COVID-19 pandemic has highlighted the importance of teaching and learning using information and communication technologies (ICTs), not only in distance learning and e-learning, but also in in-person education itself. The use of technology has been essential for ensuring that no one is left behind due to a lack of face-to-face assistance. This change has been supported by technology and driven by circumstances in the framework of digital illiteracy and widespread teacher technophobia [1]. Consequently, teachers need to acquire digital skills to apply and solve everyday teaching-learning problems. This has led us to develop the framework for a new teacher training model by promoting scenarios oriented towards digital literacy using web mapping, such as geographical information systems on the Cloud (also known as Web GIS), an important emerging geotechnology. This has allowed for the improvement of Internet competencies, such as web services, web mapping, web tools, web sensors, and 'participatory web', and the development of location-based mobile applications [2]. However, Education for Sustainability (EfS) also uses powerful knowledge [3] to respond to the needs of citizens. This includes the principle that education will transform society [4]. In the course of this research, we have integrated online collaborative and cooperative work [5] and competencies and skills to identify and address problems by defining their corresponding global and local elements. All these possibilities promote 'learning by doing' [6], by putting 
into action experiential [7,8] and meaningful learning [9] in the environment in which face-to-face, blended, or distance teaching takes place.

\subsection{The 2030 Agenda in Education}

UNESCO promotes a global or planetary citizenship that is committed to the achievement of Sustainable Development by 2030 [10]. The 17 Sustainable Development Goals (SDGs) face the global challenges and contribute to a more peaceful, tolerant, inclusive, and secure world [11]. These goals are broken down into 169 targets that interact with each other and 230 indicators to compare achievements between countries and regions, which means social justice. To achieve the targets, the collaboration of all citizens (civil society, doctors, teachers, etc.) will need to be promoted by governments, from the top administration of the states to the local authorities. For years, the Conference of Rectors of Spanish Universities [12] has been a member of the Working Group, "Curricular Sustainability", which promotes the inclusion of sustainability in universities, where teacher training programs are offered. This curricular sustainability can be defined as the transformative change that education for sustainability (EfS) entails [13], which goes beyond educating for sustainable development and beyond learning about or using sustainability only as a concept. Educating for sustainability does not simply require an 'add-on' to existing structures and curricula, but implies a change based on the ability to respond to the current crisis concerning unsustainability and the opportunities for sustainability [14]. It is possible to research and understand these matters using Web GIS (Table 1).

Table 1. Education for sustainability stages ${ }^{1}$.

\begin{tabular}{|c|c|c|c|}
\hline Teaching Approach & $\begin{array}{c}\text { About } \\
\text { (Doing Things Better) }\end{array}$ & $\begin{array}{c}\text { Using/with } \\
\text { (Doing Better Things) }\end{array}$ & $\begin{array}{l}\text { Investigate and Transform } \\
\text { (Seeing Things Differently) }\end{array}$ \\
\hline Sustainability & Learning about sustainability & Learning with sustainability & $\begin{array}{l}\text { Learning for sustainability in } \\
\text { transformative actions }\end{array}$ \\
\hline Web GIS & $\begin{array}{c}\text { Teaching and learning about } \\
\text { Web GIS }\end{array}$ & $\begin{array}{c}\text { Teaching and learning with } \\
\text { Web GIS }\end{array}$ & $\begin{array}{l}\text { Investigate and visualize in Web } \\
\text { GIS to understand and transform }\end{array}$ \\
\hline Responsibility & To the teacher & To the teacher & To the student and teacher \\
\hline
\end{tabular}

\subsection{Digital Competence in Teaching Models and Methods}

There are four key recommendations for using technology to improve teaching [16] (pp. 4-5):

- Consider how technology will improve teaching and learning before introducing it (a pedagogic rationale requires a clear plan to respond to a previously defined need).

- Technology should be used to improve the quality of explanations and modelling (it is necessary to plan teacher training carefully to use it effectively).

- Technology offers ways to improve the impact of pupil practice.

- Technology should play a role in improving assessment and feedback, which is supported by pedagogy and implementation.

The European Commission (EC) highlights digital competitiveness in the digital economy and society index (DESI) [17] using five core groups: connectivity, human capital, the use of Internet services by citizens, the integration of digital technology by business and digital public services, and research and development in information and communication technologies (ICTs). Most of these can be transformed into an applied approach to schools. Currently, integrating digital skills into teacher training is the first step towards improving teacher training, since ICT itself does not imply innovation or guarantee improvements or results in learning.

Learning outcomes respond to students' achievements through the specification of verifiable competences in a way that reflects what the student is expected to know, understand, and be able to do following the training. This means a clear, observable, achievable, 
suitable, relevant, and assessable process in the construction and improvement of knowledge, using an active pedagogy by teachers and making use of technology to enhance the spatial, sustainable, and socioemotional aspects.

Thus, the learning experience should be the stimulus that produces a change in behavior as a result of experience [18]. Most of the authors propose sequence learning in steps and 'staggered knowledge' that is meaningful, from the simplest to the most complex. Starting from previous knowledge (constructivism) is a similar process, in which the level of difficulty gradually increases [19]. There were different learning taxonomies prior to the use of an active methodology and the idea of "creating" through technology, such as those which Bloom updated [20,21], the spiral model of Bruner [22], in which a particular topic is examined increasingly deeply through iteration, and Rosenshine's updated instructional model $[23,24]$. Therefore, many learning styles, theories, and principles are focused on the student's individual progress, which does not stimulate interaction. The use of technology can offer greater interaction in all directions and allows the level of difficulty to be increased in each particular line of learning [25-27]. Additionally, learning results can be easily communicated and evaluated by students themselves (self-evaluation), socially (intragroup coevaluation by the base group and intergroup evaluation by the class group), and/or by the teacher (heteroevaluation) [28].

Some teachers who employ technology-based teaching use different didactic strategies: applying a scientific method, problem-based learning (PBL), and project-based learning and/or inquiry-based learning (IBL), in which the student can communicate, beyond the traditional exam, what s/he has learned and introduce the final product to an audience (classmates, teachers, or family members). In secondary education, all these teaching strategies have been applied using geotechnologies, such as geographic information systems (GISs) [29-31]. Recently, the GIS on the cloud or GIS Webs seems to offer both accessibility and easy handling, allowing for the visualization of geodata in a Web map.

The integration of ICT in teaching has led to new educational models and challenges, which, in turn, led to changes in methodologies. The TPACK (Technical Pedagogical Content Knowledge) model is particularly notable due to its simplicity, clarity, and applicability at all educational levels [32-35]. Additionally, it encourages teachers to integrate technologies in an applied, natural, and effective way within their own reference science [36]. Teachers who actively use ICT in teaching by combining technology, pedagogy, and the subject matter provide an example that their own students and future teachers can follow [37]. The position of the teacher is transformed, as they act in the classroom as a facilitator, who learns from their own teaching experience. The TPACK model represents an advance from the previous model based on pedagogy and content [38], adding the technological dimension and the context in which knowledge is produced [39]. Nonetheless, it lacks the socioemotional aspect necessary in all training related to attitudes and motivations, to which the model does not make specific reference, although it could be partially integrated into the pedagogical part.

\subsection{The Importance of Socioemotional Aspects in Education}

This is not the first time that a socioemotional dimension has been added to an already defined model, considering, for example, what happened to Gardner's 'multiple intelligences', after the linguistic-verbal, musical, logical-mathematical, bodily-kinesthetic, interpersonal, intrapersonal, and naturalistic intelligences were defined [40]. Emotional intelligence [41] and spiritual intelligence [42] were added. Affective aspects in teaching practice are important, because much of what the teacher knows and does is connected to their own emotional state and motivation, and this directly influences students' learning. Thus, awareness of the importance of the affective domain in emotions in relation to the content that is taught changes attitudes and improves teaching effectiveness. The affective domain is transformed and integrated in the processes of innovation and professional development in the specific and didactic contents of the subject to be taught [43]. 
Castañeda et al. [44], citing Escudero [45] (p. 12) in their scheme on the "beliefs, knowledge, capacities, and basic attitudes of the teaching identity", affirm that an expert should not only be skilled in (a) content, (b) methodologies, and (c) learning from their own practice, but must also (d) be part of the community in which they learn, (e) establish a positive relationship with the family and the student environment, and (f) be sensitive to the social and ethical imperatives of their practice. Each of these elements are closely related and important for teaching competencies, as the recent pandemic has shown, in which teachers' emotional support for students has been decisive in determining the students progress. If we combine socioemotional education for sustainability with technology, we can speak of a transformation not only of formal, non-formal, and informal education, but also of cognitive and socioemotional community learning and citizenship education [46] (p. 20), as indicated by Murga-Menoyo [47]. While much remains to be done in relation to the socioemotional competencies of teachers in the field of research to increase their scientific foundation, the existing evidence confirms that they favor the educational success of students [48].

Thus, there are also important socioemotional aspects of training teachers to shape students in their future daily lessons, as they interact with the pedagogical practice. Socioemotional competence is considered as part of the relational competence of teachers, i.e., their ability to build positive relationships [49].

The indicators for building socioemotional competence in teacher training are related to the promotion of sensitivity in acknowledging students' feelings and responsiveness in a group, being emotionally present and managing one's own and others' emotions (e.g., taking the role of the other), and confirming the student and having a sustainable emotional influence through actions and attitudes in an ongoing communicative process. This can be achieved by teaching interventions (e.g., using appropriate videos and accurate analysis reflection). It is agreed that there is a lack of research on this topic [50].

\section{Materials and Methods}

The main objective of this work is to highlight the essential elements and competencies required in geography teacher training in education for sustainability by investigating and visualizing in Web GIS to improve our understanding and moving toward a transformative attitude. This involves building a theoretical framework for teacher training necessities in responding to the current changes in the secondary school curriculum in Spain. This means the natural and productive integration of the 2030 Agenda, together with geotechnologies in their educational context, for cognitive, procedural, and socioemotional learning [47]. This has already been achieved from a geographical and social science perspective, because the authors that belong to these scientific fields.

Therefore, on the technological side, one of the main resources used has been interactive online maps to build storytelling digital maps using ArcGIS Online, TM, and Esri ${ }^{\circledR}$. These storytelling maps allow us to make environmental and social problems related to SDGs and targets understandable to students, as they are clearly visualized. A considerable amount of evidence related to education for sustainability and Education for Sustainable Development (ESD), using the proper and correct map, as in the teaching examples of action-research), was considered.

To achieve a theoretical model framework for teacher training related to the proposed objective, two methods were used in parallel. One was from the results of a mixed methodology, which was applied using different techniques. This method mainly focused on expert teachers of technology and SDGs (Table 2) from secondary schools and universities. Trainees were not considered in the theoretical framework model, which was not used in a concrete syllabus. Thus, only experts on the topic, who would have adequate knowledge on the scope of using Web GIS for SDGs learning and adoption, were considered. The second method came from action research (Table 3) on the daily lessons of the two secondary schools, in which the authors conducted their daily work. 
Table 2. Expert participants and methods.

\begin{tabular}{ccccc}
\hline Method & \multicolumn{2}{c}{ Level of Teaching } \\
\hline & University & $\begin{array}{c}\text { University/Teacher } \\
\text { Training }\end{array}$ & $\begin{array}{c}\text { Secondary School/Teacher } \\
\text { Training }\end{array}$ & Secondary School \\
Delphi $(n=15)$ & 10 & 2 & 1 & 0 \\
Questionnaire $(n=27)$ & 15 & 8 & 3 & 2 \\
In-depth interviews $(n=9)$ & 2 & 2 & 3 & 4 \\
Total $(n=51)$ & 27 & 12 & 6 & 2 \\
\hline
\end{tabular}

Table 3. Designed interventions as action research in geography secondary school lessons within the EfS framework.

\begin{tabular}{|c|c|c|c|c|c|c|}
\hline \multirow{2}{*}{$\begin{array}{l}\text { Activity Name (Level) } \\
\text { (Number of Students) }\end{array}$} & \multirow{2}{*}{$\begin{array}{l}\text { Pedagogy, Technology, } \\
\text { and Content }\end{array}$} & \multicolumn{4}{|c|}{ Competencies in Sustainability ${ }^{1}$} & \multirow{2}{*}{ Teaching Needs Detected } \\
\hline & & CA & SR & $\mathrm{CM}$ & SR & \\
\hline $\begin{array}{l}\text { A country in the rucksack } \\
\left(3 .^{\circ} \text { E.S.O. }\right)(n=240)\end{array}$ & $\begin{array}{l}\text { Cooperative learning } \\
\text { Google Sheets ArcGIS Online } \\
\text { Previous learning detection } \\
\text { on SDI and World } \\
\text { interactions }\end{array}$ & $x$ & $x$ & & & $\begin{array}{l}\text { Photography } \\
\text { Tools for cooperative work } \\
\text { Inquiry method } \\
\text { Socioemotional motivational } \\
\text { activities }\end{array}$ \\
\hline $\begin{array}{l}\text { A landscape, a treasure: Spain } \\
\text { and Europe } \\
\left(3 .^{\circ} \text { E.S.O. }\right)(n=173)\end{array}$ & $\begin{array}{l}\text { Collaborative work } \\
\text { Data from SDI } \\
\text { Web map } \\
\text { Landscape }\end{array}$ & $x$ & $x$ & $x$ & $x$ & $\begin{array}{l}\text { Web competencies } \\
\text { Active methodologies } \\
\text { Environmental awareness } \\
\text { Assessment of emotions }\end{array}$ \\
\hline $\begin{array}{l}\text { Field trip to the Spanish National } \\
\text { Park Tablas de Daimiel } \\
\left.\text { (3. }{ }^{\circ} \text { E.S.O. }\right)(n=173)\end{array}$ & $\begin{array}{l}\text { Data processing } \\
\text { GPS } \\
\text { Field trip }\end{array}$ & $x$ & $x$ & & $x$ & $\begin{array}{l}\text { Practical strategy } \\
\text { Spatial competencies } \\
\text { Aware of the protected areas }\end{array}$ \\
\hline $\begin{array}{l}\text { Are we able to transform our city? } \\
\text { Our country? And the world? } \\
\left(3 .^{\circ} \text { E.S.O. }\right)(n=172)\end{array}$ & $\begin{array}{l}\text { Flipped classroom } \\
\text { Web SIG } \\
\text { Data } \\
\text { Service Learning }\end{array}$ & $x$ & $x$ & $x$ & $x$ & $\begin{array}{l}\text { Web competencies } \\
\text { Assessment through Portfolio } \\
\text { Aware of sustainability and } \\
\text { emotions }\end{array}$ \\
\hline $\begin{array}{l}\text { The Geopolitics of } 21 \text { st Century } \\
\text { (Bilingual teaching) } \\
\left(4 .^{\circ} \text { E.S.O.) }(n=94)\right.\end{array}$ & $\begin{array}{l}\text { Data visualization: ArcGIS } \\
\text { Online } \\
\text { Collaborative: presentations } \\
\text { on keynote and } \\
\text { work on the cloud }\end{array}$ & $x$ & $x$ & $x$ & & $\begin{array}{l}\text { Web technology (e.g., Web GIS, } \\
\text { Google Drive) } \\
\text { Active methodologies } \\
\text { Aware of sustainability } \\
\text { Socioemotional assessment }\end{array}$ \\
\hline
\end{tabular}

${ }^{1}$ Abbreviations: CA: critical analysis, SR: systemic reflection, CM: collaborative decision-making, and SR: sense of responsibility towards present and future generations.

From the teachers' perspective, the techniques used in order to collect information were the Delphi technique and a small survey to be completed by university experts on GIS, teacher trainers, secondary school teachers, and professionals of GIS. The expertise of the selected informants allowed us to avoid having to draw on a larger sample.

The Delphi technique focused on the topic of data access, which serves as a source of geography knowledge. Knowledge was constructed using a technological resource, such as spatial data infrastructures (SDI), which draws on quality content, online viewers, and web maps. This technique is considered to be very suitable for a facility to be able to evaluate a particular topic. This approach was applied to teaching experts with diverse educational levels (20) and SDI technicians (4). A total of 15 is the minimum considered to be a reasonable number of participants [51] (p. 23). The approach was run between May and August 2017 [28]. The selected panelists were mainly experts on GIS technology and data access. There were two necessary iterative rounds to respond and reach a consensus on the utility of SDI for data access and the more adequate pedagogies to use it with secondary school students and trainees. A questionnaire was distributed to professors and teacher trainers with an interest in SDGs (May-December 2018). The aim was to see if they were introducing a sustainability approach in their daily lessons and detecting problems and facing difficulties associated with this. Some of the participants were experts on SDGs, who used them in their daily lessons and some others were trying to use them. The teacher questionnaire was focused on seeing the potential of SDGs in lessons, with questions about which of these 17 objectives can be addressed from the subjects/courses that the teachers teach in their daily lessons (asking about a practical case in the subject that they teach), about the method that they follow in their teaching process to achieve the necessary skills to work on the chosen SDGs in the specific subject, and about achieving the SDGs by 2030. 
However, curricular sustainability needs to go further. Action research has been required in the authors' secondary-education geography classrooms, using technology, content, and pedagogy that relate to UNESCO's sustainability competencies, as formulated by Murga-Menoyo [52]. The main EDS and EfS learning points draw on maps of local, regional, and global problems in sustainable development. This was found to be an original way of actively working with students, as it allowed them to acquire the competencies that have been integrated into a socioemotional framework and contextualized from 2016 to 2020. Table 3 collects the school interventions to gain feedback about teacher training guidelines. It has been seen that a wide range of elements and views should be considered, not only from the point of view of the teachers, but also in a particular student's context, such as the curriculum, resources, and/or the school environment.

\section{Results}

The theoretical framework for the model was produced after investigating experts' points of view and teaching experience through in-depth interviews.

\subsection{Results from the Delphi Technique}

When the Delphi technique is applied [28], the participants see the importance of geolocated data or SDI geodata for building knowledge for professionals in the territory, researchers, teachers, and citizens and for understanding the territory and its sustainability problems using structured geographic information and graphics. It is also considered to be important to acquire training to access, analyze, select, evaluate, and use geodata and geographic information technologies, including cartographic viewers. Geospatial information and communication technologies (GeoICT) have an increased utility in lessons and in daily life [31]. Thus, mapping and training in geographic information systems, both on the desktop and on the cloud, are possible additional elements for teaching and learning. Data quality does not seem to be important for teachers and students, a fact that had previously been identified in the European GI-Learner project [27], which may be one of the reasons for the appearance and proliferation of fake news. In addition, the SDI allows the use of first-hand data, which are reliable and accurate, although there are still some usability barriers. In relation to the integration of these technologies in geography lessons involved in SDGs, the respondents find the following teaching methods useful: project-based learning, resolving problems, and case studies (93.3\%), learning by discovery $(86.6 \%)$, and the flipped classroom (46.6\% of responses). Most of these learning techniques are used to promote students' critical thinking, which is a key EfS competency.

\subsection{Results from the Teacher Questionnaires}

In relation to the teacher questionnaires, all but two of the participants affirm that it is possible to integrate SDGs in the subjects that they teach, at least for one topic. The teachers are provided with a great variety of ways to integrate SDGs into their subjects, mainly using active methodologies. These teaching initiatives show the importance of using statistical resources and analysis, skills in cartography and GIS, communication and management skills, adaptability, and teamwork. However, the teachers consider that they need more training in digital methods and teaching methods. The teachers do not trust that they will be able to achieve the SDGs (Figure 1) and not all of the teachers use them frequently in their lessons. There is a clear skepticism on the topic. A Likert scale was used for this question, as it is very well accepted for measuring attitudes [53].

Some other studies show that not all the teachers are aware of the SDGs; in fact, before following a training course, they had a lack of knowledge of SDGs [54]. SDGs also need to be supplemented with the ideas put forward by Murga-Menoyo [52] (p. 68), who stresses the need for "training in skills for sustainable development", which are made up of "multiple interrelated facets", including critical analysis, systemic reflection, a sense of responsibility (for the current world and future generations), democratic commitment, human rights, and SDGs, which are all adapted from UNESCO. 


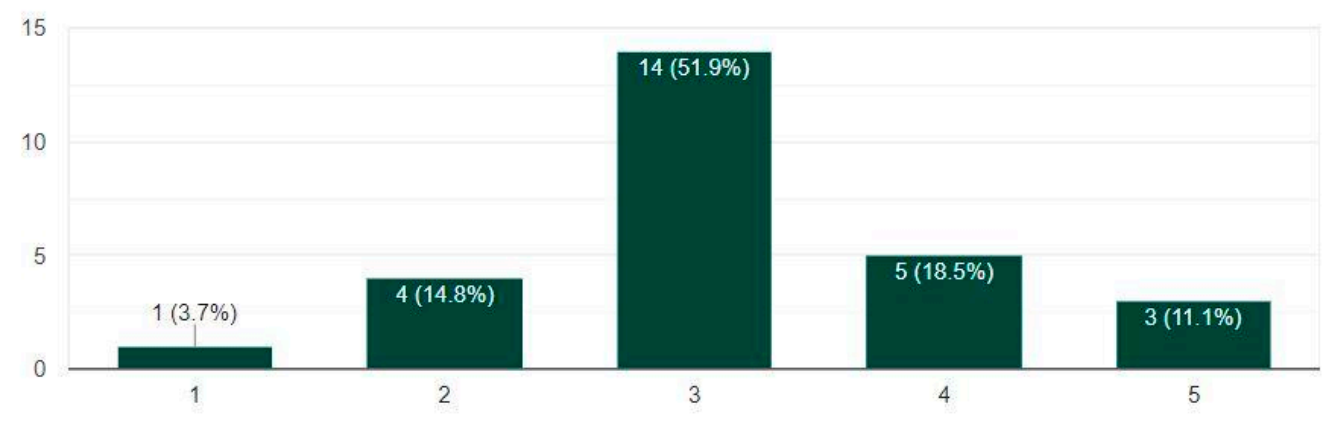

Figure 1. On a Likert scale, the teachers' $(n=27)$ responses to the question: Do you think the SDGs will be achieved by 2030 ?

\subsection{Results from the Teaching Interventions Using Digital Interactive Map-Based Learning}

The web maps used have been enriched with new layers from other sources of data, such as SDI or our own data. Students use hands-on web mapping to work on ODS issues to achieve EfS. Some practical local and personal actions come from these initiatives related to water, energy, or rubbish management, among other things. Socioemotional challenges arise from these actions. From a quantitative point of view, more than $80 \%$ of students gain a knowledge of SDGs, from having a poor or scarce SDG knowledge. From a qualitative point of view, the main indicators of learning achievement are to identify sustainability problems and interrelations, see the long-term effects, and detect options of improvement at different scales (personal, local, and global).

As a result of the teaching interventions with secondary school students, some teaching needs were identified (Table 3), such as technology management of web resources (e.g., Web and Apps competencies), including digital portfolio, Web GIS, Google Drive, and some skills in photography and images, knowledge of active pedagogy methods, such as cooperative learning and inquiry methods, and awareness of the environment and sustainability. Additionally, they gain an understanding of socioemotional and motivational aspects, which is not an easy task.

\subsection{Results from the In-Depth Interviews}

Our observations of the first draft of the theoretical model (Appendix A), taking into account all the aspects observed in the previous results, were used as the basis of the interviews. Some of them were made in pairs to foster discussion and suggestions for input. The experts validated the following broad categories: academic, pedagogical, technological, and SDG integration using emotions to enhance world transformation in terms of sustainability issues.

\section{The Framework for a Theoretical Model}

Thus, it has been considered necessary to produce a teacher training model that integrates sustainability skills using technologies and environmental concerns and emotions, which are clearly linked to the SDGs. This model will be explained using the categories that were validated by the experts.

The academic aspects that correspond to the content of the discipline to be taught are mainly science, technology, engineering, arts, and mathematics; however, in our particular case, geography and social science were also included. The preparation is usually carried out by the university in the initial and continuous training of teachers, which is an indisputable need.

The pedagogical aspects related to the teaching strategies and techniques that are proposed for the integration of content, technologies, and the achievement of sustainable actions within the framework of the 2030 Agenda. These strategies are based on active teaching, such as those cited by the expert panelists for the Delphi technique and those that have been put into action in the classroom interventions outlined above. As noted, these include project-based learning, problem-based learning, cooperative work, geospatial 
comprehension projects, and didactic outputs that incorporate Web GIS technology, including viewers. The flipped teaching model is useful for advancing the cognitive aspects and thus the contents of the discipline that students have to know. In addition, service learning can be used to create a social service delivered by students to any social agent of the local community. Tejedor et al. [55] and Bezanilla et al. [56] also consider these to be important for higher-education case studies and didactic simulation strategies (it should be noted that this new language of telling stories using online interactive maps is not among the critical learning examples analyzed by the authors). Learning is affected by the pedagogy associated with the technology application used in the classroom [57].

The technological aspects are used in obtaining, analyzing, and processing information and data in order to build knowledge. The assessment of the data's quality and reliability, and its thematic, spatial, and temporal components, is made possible using statistical programs and quantitative and qualitative analysis, for which dissemination communication tools are necessary. In this way, ICT is complemented by technologies that favor learning and knowledge, which serve as a communication vehicle in the teaching-learning process. Thus, in the process of designing activities for the construction of knowledge and its communication, images, texts, statistics, mathematical reasoning, and maps were all used on the cloud or developed locally on the computer itself, among many other resources. In matters related to territory and environmental concern, cartographic viewers and Web GIS play an important role, since they allow for the visualization, analysis, and interpretation of the territory. The teacher must apply ICT tools smoothly in the European framework of the Digital Competence of Educators (DigCompEdu) [58,59] and citizens [60] or be willing to learn them "on demand" in their own teaching practice or daily life. The challenge is for students/future teachers to "learn by doing" using these tools and acquire digital skills that are then transferred to the real contexts of their academic life and their future work teaching in schools and high schools. Additionally, on the technology side, a user-centered design (UCD) approach, traditionally used in business, should involve teachers so that the tools are designed to respond to teaching needs $[61,62]$. It is possible to achieve this using geotechnologies [63].

The integration of SDGs means going beyond an environmentalist approach to content, which most teachers are familiar with. However, the application of scientific evidence, which is frequently obtained or visualized using technology, must lead to a transformation of the individual in relation to environmental solidarity (ecological, economic, and social) [52]. Thus, sustainable values appear as a key element of the curriculum (curricular sustainability) and an educational and moral guide for the student, who is capable of transforming the environment at a "glocal" scale, as Murga-Menoyo [52] calls it, which means all possible geographical scales: global, regional, and local. In this way, the student engages with the need for curricular sustainability and the training of responsible citizens. Thus, competences in sustainability appears as essential [64] for the effective teaching and learning assessment.

Socioemotional aspects play a key role in learning and they are mostly related to multiple intelligences, curricular knowledge, and the content that is taught [43]. However, they are also related to technological, pedagogical, and sustainable aspects. Socioemotional education occupies the central place, because the teaching process must start from there, so teachers should be trained in it.

A clear teacher training plan must cover all indicated aspects, based on real needs, focusing technology on the user, planning attractive and varied content, and creating an inclusive educational practice that connects an educational technology practice with the current curriculum using the appropriate pedagogical and socioemotional framework. Furthermore, this plan must employ active methodologies that promote the work of students with organizations in their local environment, such as service learning (a learning strategy that is necessary for changing attitudes) [28], together with a conceptual design that supports problem solving and case studies. Critical analysis, systemic reflection, collaborative decision making, a sense of responsibility (towards the current world and 
future generations), democratic commitment, human rights, and SDGs [52] are all essential for citizen and planetary solidarity.

This teacher training framework model arises from the identification of needs and incorporates a number of innovations [65]: new processes, products, services, and knowledge. The model focuses on the users (i.e., the teachers and students), both in terms of the use of pedagogical strategies and the adaptation of technology to them, rather than the other way around, i.e., the promotion of teaching personalization strategies [66], as the socioeconomic context is very important for improving competencies in sustainability.

Thus, the extensive knowledge that a teacher must have of the subject, accompanied by his/her didactic application of technology and sustainability skills, is not only important, but it should also be based on socioemotional education and curricular sustainability. The proposed teacher training framework model includes the aforementioned components, with three from the TPACK model [39] and collaboration in the achievement of the SDGs in the territory. The context of the model has also now been deepened, so that it relates to values and positive and negative emotions. A Venn diagram has been used (Figure 2) to represent this after it was validated by expert participants in in-depth interviews.

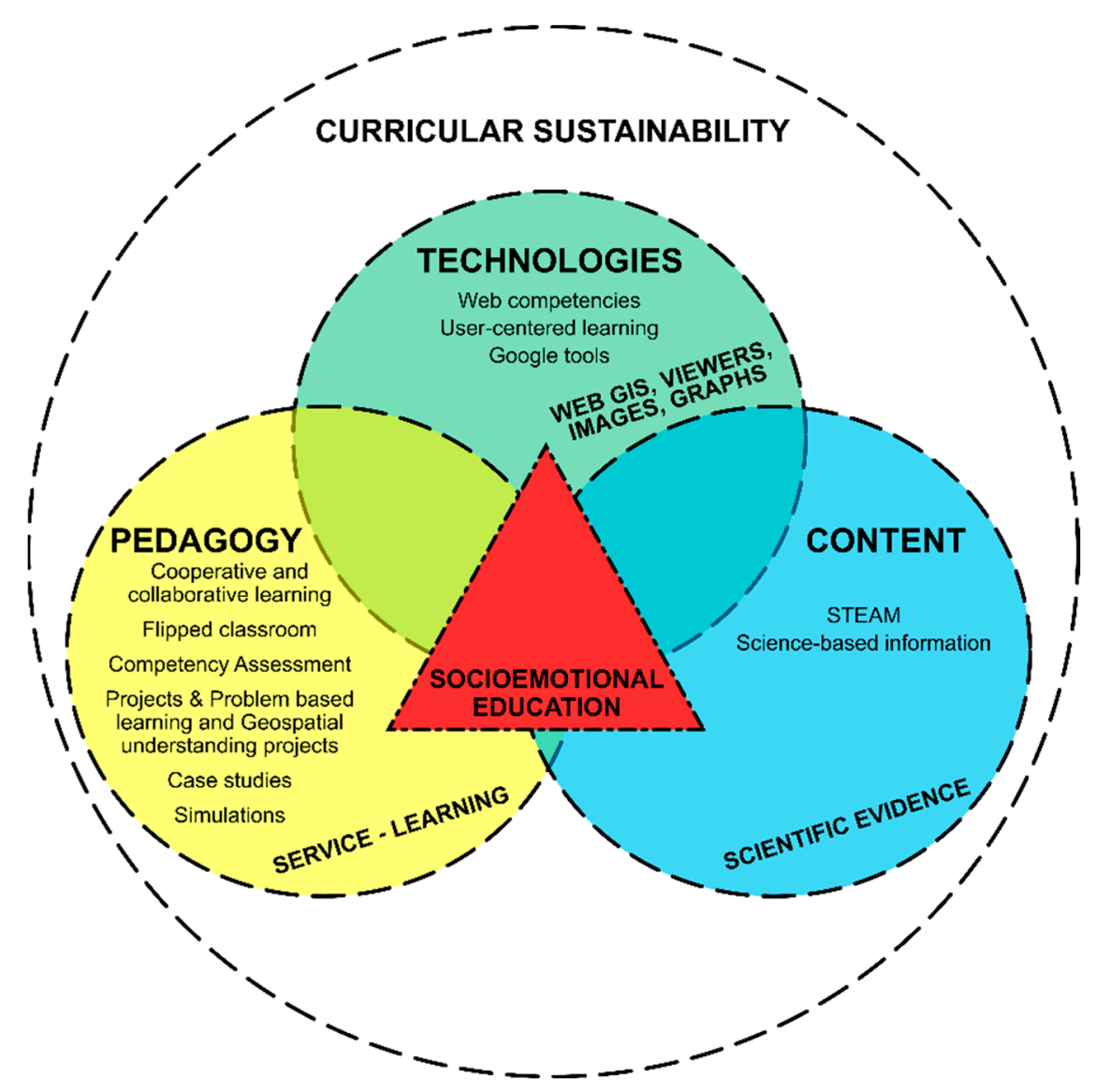

Figure 2. Teacher training framework model to improve competencies in sustainability. A wide range of elements and views have been considered, such as curricular sustainability, resources, and the school environment. However, socioemotional education should be at the core.

The results of the groups of teachers and professionals and these different techniques have served to develop and agree about each of the key elements of the teacher training model to be built, while contributing to the SDGs. Globally, it seems that the sources of data are very useful for building web maps and knowledge-related SDGs. The model enhances the curricular sustainability and a truly transformative quality education, using learning achievements adjusted to a top-level typology of competencies for sustainability. Each is made up of a cluster of many other competencies with multiple elements: knowledge, 
values, skills, attitudes, etc., which is a synergistic effect of their interrelation [67] and makes it possible to maintain socioemotional education in the core and employ curricular sustainability as the framework. This is a new method, which needs to be explored by researchers and society.

This teacher training model and framework make it possible for teachers to integrate all the necessary elements to build local and global citizenship in the 21st century into their daily teaching. Thus, the data ecosystem that the digital revolution provides as information is highly applicable to the educational activity, not only for generating knowledge, but also for promoting skills and competencies related to sustainability, as explained above. This involves focusing attention on the comprehensive training of the person, who is understood to be a member of the community that constitutes the biosphere. The aim is to produce a citizen who is actively committed to democracy, inclusivity, universal equity, and solidarity [47]. Figure 3 provides a scheme that summarizes this process.

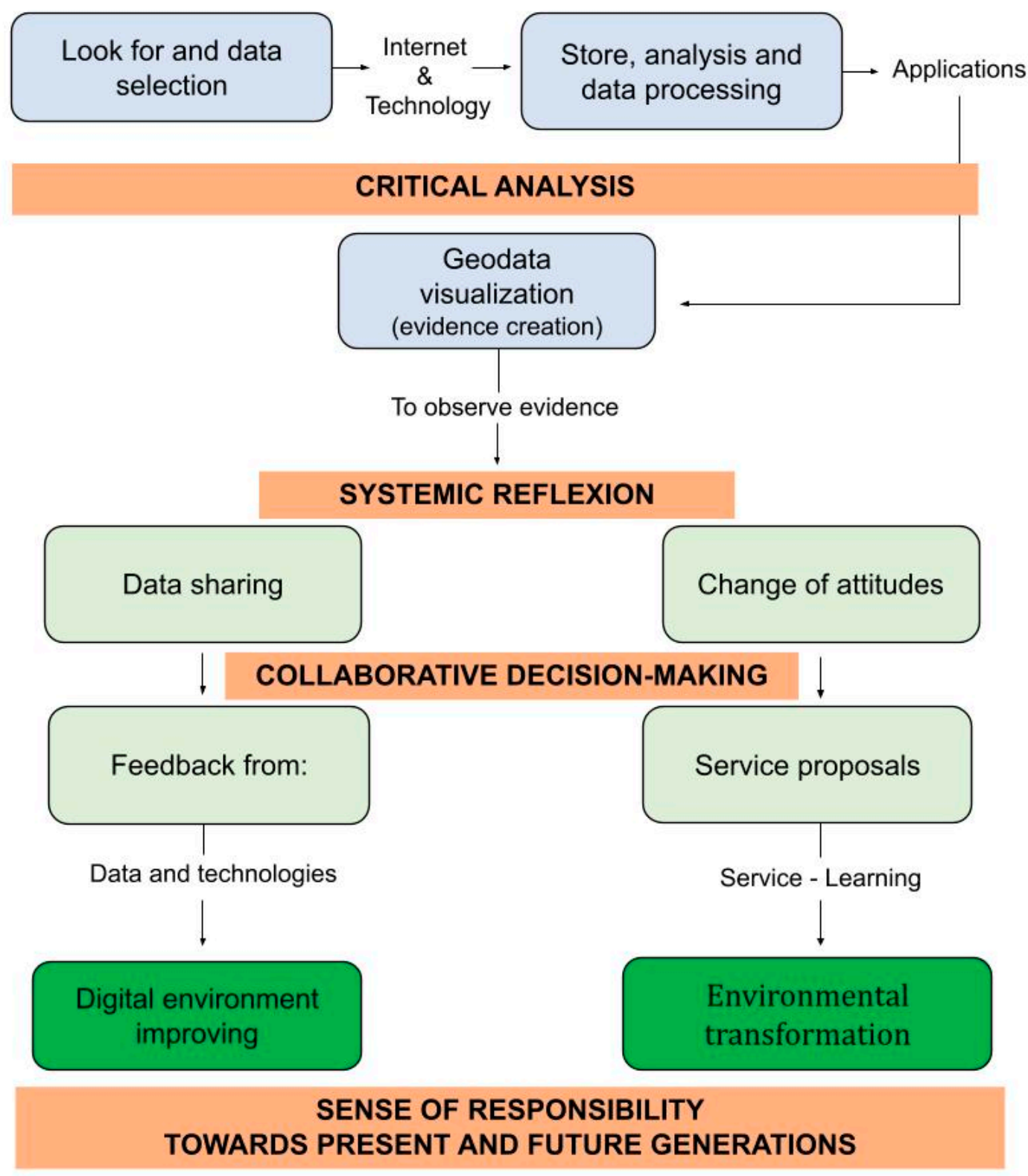

Figure 3. Process to acquire competencies in sustainability based on Álvarez-Otero [28].

Additionally, learning results take into account the whole process (Figure 2) and can easily be shared with a learning community and collaborative groups [68,69]. 


\section{Discussion and Conclusions}

The key elements of the teacher training model to achieve learning outcomes and competencies for sustainability means taking transformative action. This means not only using a theoretical framework as the basis of a model to be adapted individually by any educational institution according to its own needs, but also socioemotional competencies.

Quality preservice and in-service teacher training are ongoing challenges in our educational system [45]. We should seek to produce a global and caring planetary citizen who contributes towards a sustainable planet. In order to achieve this, a path has been identified for teacher training, in which the use of technology for data processing allows for student-centered learning, the construction of knowledge, and critical thinking using critical analysis (in which aspects of social justice, human rights, and sustainability are incorporated). Students should understand that there are no absolute truths and that consensus is an important value. Furthermore, they should acquire digital literacy to help them to be active and constructive citizens.

This teacher training model has been developed by employing the Delphi method and questionnaires for "expert" teachers, the authors' teaching experience using action research methodology, and, finally, validation of the model by other teachers who use technologies and are concerned about sustainability issues. It is based on UNESCO's sustainability competencies, which encompasses technology, the scientific content of the subject to be taught, and didactics (pedagogy) linked with innovation, but it also includes education in sustainability and socioemotional issues, with experiential knowledge of the SDGs integrated.

Thus, it is essential to have competent teachers in technology, sustainability, the subject matter of the curriculum, didactic strategies, and innovation, who take into account the context in which the teaching-learning process takes place and the management of socioemotions. While a teacher training model is important, so is an appropriate curriculum that addresses sustainability problems, because this endows it with meaning for technologically adept students.

Pedagogical strategies based on active teaching are very important and real methodological change is necessary in the classrooms, using the pillars of education: learning to know, enhancing knowing how to do and how to be (learning to do and learning to be), knowing how to be persistent (attitudes and values), and learning to live together. This approach is expected to produce changes in student attitudes that contribute to their goals and lead them to feeling positive about their experience.

Education is the key question in increasing citizens' awareness of sustainable development goals. Thus, it is essential to integrate the 2030 Agenda in teacher training, together with a socioemotional education. A complete framework for a teacher training model was created, based not only on digital competences, the scientific content of the subject, and pedagogy, but also on education in sustainability and emotional education.

Author Contributions: Conceptualization, M.-Á.P.-A.; investigation, M.-Á.P.-A.; methodology, M.Á.P.-A. and J.Á.-O.; Formal analysis, J.Á.-O.; funding acquisition, M.-L.d.L.-T.; writing-original draft, M.-Á.P.-A. and J.Á.-O.; writing-reviewing \& editing, M.-L.d.L.-T. All authors have read and agreed to the published version of the manuscript.

Funding: This research was funded by «La alfabetización ecosocial: un elemento central en los procesos de sostenibilización curricular para el logro de la Agenda 2030 (ODS) en la formación inicial del profesorado (PRAD-ODS)» "Ecosocial literacy: a central element in the processes of curricular sustainability for the achievement of the 2030 Agenda (SDG) in initial teacher training" (RTI2018095746-B-I00), (Ministry of Science, Innovation and Universities). And Innovative Pedagogies for Teaching with Geoinformation (GI-Pedagogy) (2019-1-UK01-KA203-061576) KA2-Cooperation for Innovation and the Exchange of Good Practices. KA203 - Strategic Partnerships for higher education (European Commission). The APC was funded by UNED.

Institutional Review Board Statement: Not applicable.

Informed Consent Statement: Not applicable. 
Data Availability Statement: The data presented in this study are available on request from the corresponding author.

Conflicts of Interest: The authors declare no conflict of interest.

\section{Appendix A}

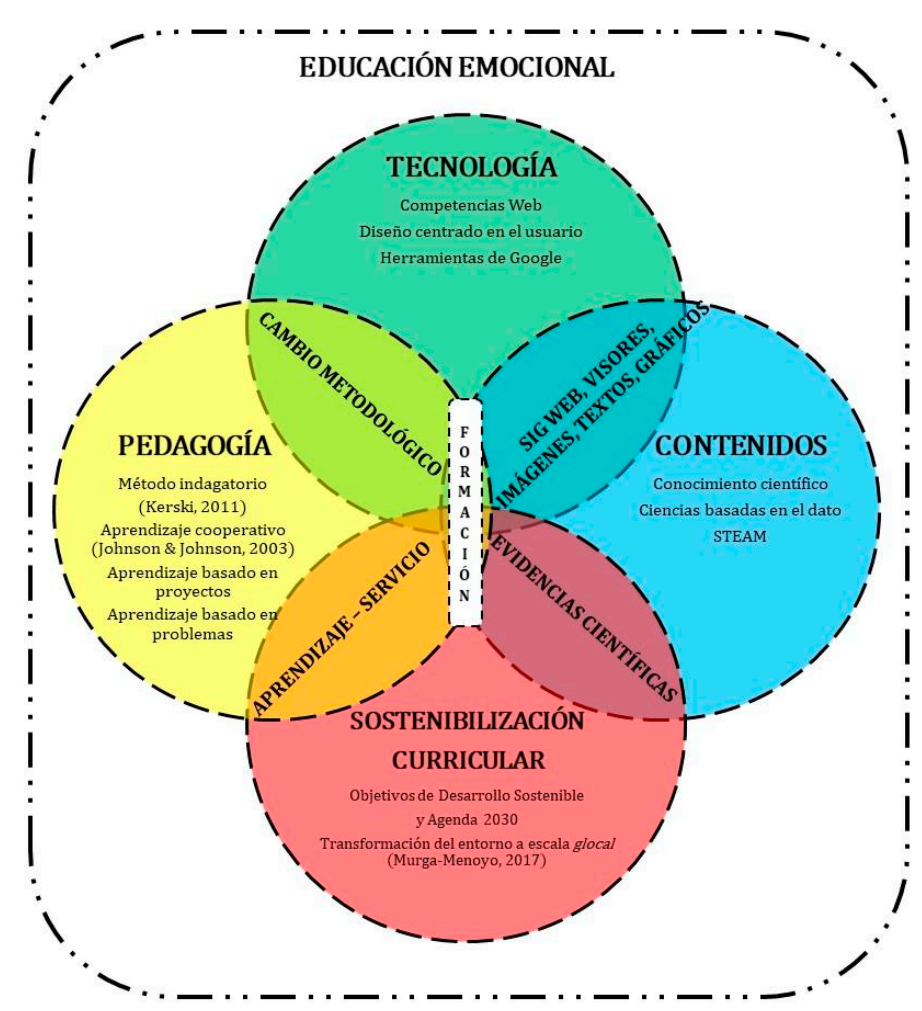

Figure A1. First draft of the theoretical model for a further experts' discussion (in-depth interviews).

\section{References}

1. Morales Capilla, M.; Trujillo Torres, J.; Raso Sánchez, F. Percepción del profesorado y alumnado universitario ante las posibilidades que ofrecen las TIC en su integración en el proceso educativo: Reflexiones, experiencias e investigación en la Facultad de Educación de Granada. EDMETIC 2015, 5, 113-142. [CrossRef]

2. Rip, F.I.; van Lammeren, R.J.A.; Bergsma, A.R. Analysis of the Supply of Geospatial Education and Training-Results of the GI-N2K Supply Survey; GI-N2K: Salzburg, Austria, 2014. Available online: http:/ /www.gi-n2k.eu/surveys-results/ (accessed on 8 June 2021).

3. Dangalle, N. Powerful knowledge with Geography. Sri Lanka J. Soc. Sci. 2021, 44, 115-117. [CrossRef]

4. UNESCO. Education for Sustainable Development Goals: Learning Objectives. 2017. Available online: https://unesdoc.unesco. org/ark:/48223/pf0000247444 (accessed on 8 June 2021).

5. Johnson, D.W.; Johnson, R.T.; Stanne, M.B. Cooperative Learning Methods: A Meta-Analysis. 2000. Available online: https: / / bit.ly/3hHj5Vc (accessed on 8 June 2021).

6. Labouta, H.I.; Kenny, N.A.; Li, R.; Anikovskiy, M.; Reid, L.; Cramb, D.T. Learning science by doing science: An authentic science process learning model in postsecondary education. Int. J. Sci. Educ. 2018, 40, 1476-1492. [CrossRef]

7. Kolb, D.A. Experiential Learning: Experience as the Source of Learning and Development; Prentice-Hall: Englewood Cliffs, NJ, USA, 1984. Available online: https:/ / bit.ly/3b4ye1B (accessed on 19 May 2021).

8. Kolb, D.A.; Boyatzis, R.E.; Mainemelis, C. Experiential learning theory: Previous research and new directions. Perspect. Think. Learn. Cogn. Styles 2001, 1, 227-247. [CrossRef]

9. Elosúa de Juan, M.R. El aprendizaje significativo desde un enfoque social. Rev. Psicol. Univ. Tarraconensis 1992, 14, 7-16.

10. UNESCO. Incheon Declaration and Framework for Action for the Implementation of Sustainable Development Goal 4: Ensure Inclusive and Equitable Quality Education and Promote Lifelong Learning Opportunities for All. 2015. Available online: https:/ / unesdoc.unesco.org/ark:/48223/pf0000245656 (accessed on 19 May 2021). 
11. UN. Global Indicator Framework for the Sustainable Development Goals and Targets of the 2030 Agenda for Sustainable Development. Adopted by the General Assembly in A/RES/71/313 (Annex), Annual Refinements Contained in E/CN.3/2018/2 (Annex II), E/CN.3/2019/2 (Annex II), 2020 Comprehensive Review Changes (Annex II) and Annual Refinements (Annex III) Contained in E/CN.3/2020/2 and Annual Refinements (Annex) Contained in E/CN.3/2021/2. 2021. Available online: https:/ / unstats.un.org/sdgs/indicators /Global\%20Indicator\%20Framework\%20after\%202021\%20refinement_Eng.pdf (accessed on 19 May 2021).

12. CRUE-CADEP. Directrices Para la Introducción de la Sostenibilidad en el Curriculum Propuesta por el Comité Ejecutivo del Grupo de Trabajo de CADEP (Calidad Ambiental y Desarrollo Sostenible). 2012. Available online: http://www.crue.org/ Sostenibilidad/CADEP/Documents/DIRECTRICES\%20SOSTENIBILIDAD\%20CRUE\%202012.pdf (accessed on 19 May 2021).

13. Bautista-Cerro Ruiz, M.J.; Murga-Menoyo, M.Á.; Novo, M. La Educación Ambiental en el S. XXI. (página en construcción, disculpen las molestias). Rev. Educ. Ambient. Sostenibilidad 2019, 1, 1103. [CrossRef]

14. Sterling, S. Higher Education, Sustainability and the Role of Systemic Learning. In Higher Education and the Challenge of Sustainability: Problematics, Promise and Practice; Corcoran, P.B., Wals, A.E.J., Eds.; Kluwer Academic: Dordrecht, The Netherlands, 2004; pp. 49-70.

15. Favier, T. Geo-Informationtechnologie in Het Voortgezet Aardrijkskundeonderwijs: Een Brochure voor Docenten; Vrije Universiteit Amsterdam: Amsterdam, The Netherlands, 2013; 80p.

16. Stringer, E.; Lewin, C.; Coleman, R. Using Digital Technology to Improve Learning: Guidance Report; Education Endowment Foundation: London, UK, 2019. Available online: https:/ / bit.ly /3odVm1p (accessed on 19 May 2021).

17. European Commission. Digital Economy and Society Index (DESI). 2020. Available online: https://bit.ly/35aq2ZJ (accessed on 19 May 2021).

18. Hilgard, E.R.; Marquis, D.G. Conditioning and Learning; Appleton-Century-Crofts: Norwalk, CT, USA, 1940.

19. Novak, J.; Gowin, D. Aprendiendo a Aprender; Martínez Roca: Barcelona, Spain, 1988.

20. Bloom, B.S. (Ed.) Taxonomy of Educational Objectives: The Classification of Educational Goals; Handbook 1: Cognitive Domain; David McKay: Dysart, UK, 1956.

21. Anderson, W.; Krathwohl, D. (Eds.) A Taxonomy for Learning, Teaching, and Assessing: A Revision of Bloom's Taxonomy of Educational Objectives; Longman: New York, NY, USA, 2013. Available online: https:/ /bit.ly/354ufhO (accessed on 19 May 2021).

22. Bruner, J.S. Toward a Theory of Instruction; The Belknap Press of Harvard University Press: Cambridge, MA, USA, 1966.

23. Rosenshine, B. Principles of Instruction; Educational Practices Series, 21; International Academy of Education: Brussels, Belgium, 2010. Available online: https:/ / bit.ly /3ft5wK0 (accessed on 19 May 2021).

24. Sherrington, T. Rosenshine's Principles in Action; John Catt Educational: Woodbridge, UK, 2019.

25. Cruz, L.; Cunningham, K.; Smentkowski, B.; Steiner, H. The SoTL scaffold: Supporting evidence-based teaching practice in educational development. Improv. Acad. 2019, 38, 50-66. [CrossRef]

26. Salmon, G. E-Tivities: The Key to Active Online Learning; Routledge: London, UK, 2013.

27. Zwartjes, L.; de Lázaro y Torres, M.L. Geospatial Thinking Learning Lines in Secondary Education: The GI Learner Project. In Geospatial Technologies in Geography Education. Key Challenges in Geography; De Miguel González, R., Donert, K., Koutsopoulos, K., Eds.; UROGEO Book Series; Springer: Cham, Switzerland, 2019. [CrossRef]

28. Álvarez-Otero, J. El Uso Educativo de las Infraestructuras de Datos Espaciales (IDE) Para Mejorar la Responsabilidad Social de los Ciudadanos del Siglo XXI Sobre el Territorio. Ph.D. Dissertation, Universidad Complutense de Madrid, Madrid, Spain, 2020. Available online: https:/ / eprints.ucm.es/id/eprint/64592/1/T42185.pdf (accessed on 19 May 2021).

29. Kerski, J.J. Sleepwalking into the Future-The Case for Spatial Analysis Throughout Education. In Learning with GI 2011; Jekel, T., Koller, A., Donert, K., Vogler, R., Eds.; Herbert Wichmann Verlag, VDE VERLAG GMBH: Berlin/Offenbach, Germany, 2011; pp. 2-11. Available online: https:/ / bit.ly /2GGZioq (accessed on 19 May 2021).

30. Favier, T. Geographic Information Systems in Inquiry-Based Secondary Geography Education: Theory Practice. Ph.D. Thesis, VU University Amsterdam, Amsterdam, The Netherlands, 2011. Available online: https:/ / bit.ly/3rOXLlf (accessed on 9 February 2021).

31. Kolvoord, R.A. Fostering spatial thinking skills for future citizens to support sustainable development. Cult. Sci. 2021, 20966083211024714. [CrossRef]

32. Gómez-Trigueros, I. Digital Teaching Competence and Space Competence with TPACK in Social Sciences. Int. J. Emerg. Technol. Learn. 2020, 15, 37-52. [CrossRef]

33. Graham, C.R.; Burgoyne, N.; Cantrell, P.; Smith, L.; St Clair, L.; Harris, R. TPACK Development in Science Teaching: Measuring the TPACK Confidence of Inservice Science Teachers. TechTrends Link. Res. Pract. Improv. Learn. 2009, 53, 70-79. [CrossRef]

34. Melo Hernández, M.E. La Integración de las TIC Como Vía para Optimizar el Proceso de Enseñanza Aprendizaje en la Educación Superior en Colombia. Ph.D. Thesis, Universidad de Alicante, Alicante, Spain, 2018. Available online: https://bit.ly/3hDHMlv (accessed on 19 May 2021).

35. Voogt, J.; Fisser, P.; Pareja Roblin, N.; Tondeur, J.; van Braak, J. Technological pedagogical content knowledge: A review of the literature. J. Comput. Assist. Learn. 2013, 29, 109-121. [CrossRef]

36. De Lázaro y Torres, M.L.; Izquierdo Álvarez, S.; González González, M.J. Geodatos y paisaje: De la nube al aula universitaria. BAGE 2016, 70. [CrossRef]

37. Tømte, C.; Enochsson, A.B.; Buskqvist, U.; Kårstein, A. Educating online student teachers to master professional digital competence: The TPACK-framework goes online. Comput. Educ. 2015, 84, 26-35. [CrossRef] 
38. Shulman, L.S. Those who understand: Knowledge growth in teaching. Educ. Res. 1986, 15, 4-14. [CrossRef]

39. Mishra, P. Considering Contextual Knowledge: The TPACK Diagram Gets an Upgrade. J. Digit. Learn. Teach. Educ. 2019, 35, 76-78. [CrossRef]

40. Gardner, H. Frames of Mind: The Theory of Multiple Iintelligences; Basic Books: New York, NY, USA, 1983.

41. Goleman, D. Emotional Intelligence; Bantam: New York, NY, USA, 1995.

42. Gardner, H. Multiple Intelligences: New Horizons; Basic Books: New York, NY, USA, 2006.

43. Melo, L.; Cañada, F. Emociones que emergen durante el análisis del conocimiento didáctico del contenido sobre el campo eléctrico. Ciência Educ. 2018, 24, 57-70. [CrossRef]

44. Castañeda, L.; Esteve, F.; Adell, J. ¿Por qué es necesario repensar la competencia docente para el mundo digital? Rev. Educ. Distancia 2018, 56, 6. [CrossRef]

45. Escudero, J.M. Un cambio de paradigma en la formación continuada del profesorado: Escenario, significados, procesos y actores. Qurriculum Rev. Teoría Investig. Práctica Educ. 2020, 33, 97-125. [CrossRef]

46. UN. Implementation of Education for Sustainable Development in the Framework of the 2030 Agenda for Sustainable Development. A/74/258. 2019. Available online: https://undocs.org/pdf?symbol=en/A/74/258 (accessed on 1 June 2021).

47. Murga-Menoyo, M.A. El camino hacia los ODS: Conformar una ciudadanía planetaria mediante la educación. Comillas J. Int. Relat. 2020, 19, 1-11. [CrossRef]

48. Llorent, V.J.; Zych, I.; Varo-Millán, J.C. Competencias socioemocionales autopercibidas en el profesorado universitario en España. Educ. XX1 2020, 23, 297-318. [CrossRef]

49. Aspelin, J.; Jönsson, A. Relational competence in teacher education: Concept analysis and report from a pilot study. Teach. Dev. 2019, 23, 264-283. [CrossRef]

50. Aspelin, J. Enhancing pre-service teachers' socio-emotional competence. Int. J. Socioemot. Educ. 2019, 11, 153-158. Available online: https: / / www.um.edu.mt/ijee (accessed on 2 June 2021).

51. López-Gómez, E. El método Delphi en la investigación actual en Educación: Una revisión teórica y metodológica. Educ. XX1 2018, 1, 17-40. [CrossRef]

52. Murga-Menoyo, M.A. Competencias para el desarrollo sostenible: Las capacidades, actitudes y valores meta de la educación en el marco de la agenda global post-2015. Foro Educ. 2015, 13, 55-83. [CrossRef]

53. Corbeta, P. Metodología y Técnicas de Investigación Social; McGrawHill: Madrid, Spain, 2003.

54. García-González, E.; Jiménez-Fontana, R.; Azcárate, P. Education for Sustainability and the Sustainable Development Goals: Pre-Service Teachers' Perceptions and Knowledge. Sustainability 2020, 12, 7741. [CrossRef]

55. Tejedor, G.; Segalàs, J.; Barrón, Á.; Fernández-Morilla, M.; Fuertes, M.T.; Ruiz-Morales, J.; Gutiérrez, I.; García-González, E.; Aramburuzabala, P.; Hernández, À. Didactic strategies to promote competencies in sustainability. Sustainability 2019, 11, 2086. [CrossRef]

56. Bezanilla, M.J.; Fernández-Nogueira, D.; Poblete, M.; Galindo-Domínguez, H. Methodologies for teaching-learning critical thinking in higher education: The teacher's view. Think. Skills Creat. 2019, 33, 100584. [CrossRef]

57. Quinn, M. Digital Schools? Teachers Still Matter. Available online: https:/ / bit.ly/2XaASe1 (accessed on 3 June 2021).

58. Vuorikari, R.; Punie, Y.; Carretero Gomez, S.; Van Den Brande, G. DigComp 2.0: The Digital Competence Framework for Citizens; Update Phase 1: The Conceptual Reference Model; EUR 27948 EN; Publications Office of the European Union: Luxembourg; Joint Research Center: Seville, Spain, 2016. [CrossRef]

59. Caena, F.; Redecker, C. Aligning teacher competence frameworks to 21st century challenges: The case for the European Digital Competence Framework for Educators (DIGCOMPEDU). Eur. J. Educ. 2019, 54, 356-369. [CrossRef]

60. Carretero Gomez, S.; Vuorikari, R.; Punie, Y. DigComp 2.1: The Digital Competence Framework for Citizens with Eight Proficiency Levels and Examples of Use; Publications Office of the European Union: Luxembourg, 2017. [CrossRef]

61. Hong, J.E.; Stonier, F. GIS in-service teacher training based on TPACK. J. Geogr. 2015, 114, 108-117. [CrossRef]

62. Hong, J.E. Designing GIS learning materials for K-12 teachers. Technol. Pedagog. Educ. 2017, 26, 323-345. [CrossRef]

63. Lee, H.; Kim, M. The Pedagogical Effects of Student-Centered Convergence Project Class Using Geospatial Services. J. Korean Assoc. Geogr. Environ. Educ. 2021, 29, 53-69. [CrossRef]

64. Tomás, M.P.; Murga-Menoyo, M.A. El marco curricular de la Educación Secundaria Obligatoria: Posibilidades para la formación de competencias en sostenibilidad. Rev. Int. Comun. Desarro. 2020, 3, 90-109. [CrossRef]

65. Ramírez-Montoya, M.S.; Ocando, J.L. Revisión sistemática de métodos mixtos en el marco de la innovación educativa. Comun. Rev. Cientifica Iberoam. Comun. Educ. 2020, 65, 9-20. [CrossRef]

66. Moreno, A. Personalizar, un Modelo para una Educación de Calidad en el Siglo XXI. Informe Delphi de Expertos; Impuls Educació: Barcelona, Spain, 2020; pp. 1-39. Available online: https:/ / bit.ly/3rZ6bH1 (accessed on 3 June 2021).

67. Murga-Menoyo, M.Á. Education in the Anthropocene. Possibilism versus utopia. Teoría Educ. Rev. Interuniv. 2021, 33, 107-128. [CrossRef]

68. Ammoneit, R.; Reudenbach, C.; Turek, A.; Nauß, T.S.; Peter, C. Geographische Modellierkompetenz-Modellierung von Raum konzeptualisieren. GW-Unterricht 2020, 1, 19-29. [CrossRef]

69. De Souza Cavalcanti, L.; Alves Dos Santos, L. Formar para la docencia en Geografía: Un camino para la cooperación. Didáctica Geográfica 2020, 21, 19-39. [CrossRef] 